\title{
Study of the Development of Institutionalism in Electric-Power Industry
}

\section{Burganov Rais Abrarovich}

\author{
Doctor of Economics, Professor, Kazan State Power Engineering University, Kazan, Russian Federation \\ Email: burganov-r@mail.ru
}

\section{Bystrov Gennady Mixailovich}

Candidate of Economic Sciences, Associate Professor, Kazan branch of the Plekhanov Russian University of Economics, Kazan, Russian Federation Email: box041074@yandex.ru

\section{Burganov Bulat Raisovich}

Graduate Student, Kazan Federal University, Kazan, Russian Federation

Email: bulat.b-85@mail.ru

\section{Doi:10.5901/mjss.2015.v6n4s2p562}

\section{Abstract}

Object of research - the institutional environment of power industry. The article considers the institutional aspects of the development of the electric power industry. The undertaken large-scale transformations in the Russian electric power industry are not perfect yet. There should be conducted a tedious research and practical work on the creation of an effective institutional structure. The creation of electric power industry based on a new institutional structure will allow smoothing unstable condition of the national economy. Research methods: system and institutional approach, analysis and comparison of these various researches, use of empirical materials. The results show that, now in world economy it is necessary to pay attention to creation of the effective institutional environment of power. Institutional environment energy sphere is an integrated system of institutional support activities, development of human and social capital, industrial and economic growth. Reliability, quality, convenience, efficiency and availability of energy products and services, fast and cheap connection to power grids, the establishment of the institutional framework for consumers should be an important priority in the country's economic policy.

Keywords: institutional changes, electric-power industry, energy efficiency, intellectual energy engineering.

\section{Introduction}

Nowadays, the development of electric-power industry requires a thorough scientific basis. Modern problems of development of Russian energy are not only related to the technological features of the industry, but also to the institutional framework of its operation and development.

The development of the institutional environment of electric-power industry is not backed by the theoretical basis. Meanwhile, recent years' deep and ambiguous institutional reforms in the electric-power industry have caused a certain tension in the society. The study of institutional foundations of optimization in energy sector is the imperative of our time (Burganov. 2014). In particular, according to the statistics of the Supreme Arbitration Court of Russia (FAS), the number of proceedings regarding the negotiation and execution of energy supply contracts tends to increase every year.

Thus, the relevance of the study is connected with the need to consider the characteristics and methods of institutionalizing the electric power industry.

The purpose of the study is to identify the condition and perspectives of the development of theoretical and methodological framework of researches of institutional changes in the electric-power industry of the national economy.

\section{Literature Review}

Theoretical-institutional research in this area could be based on the concepts of the theory of contacts, the multiplicity of interests, the Pareto principle, etc. In the historical and economic aspects, the theories of institutional changes explained the manifestation of institutions in the electricity sector in different ways, in particular, regarding the property institution. D. 
North defined institutions as structural forms of human interactions (North, 1990). In modern foreign studies on the topic of scientific activity can be noted Polanyi K., O'Sullivan A., Eggertsson T., Rodrik D., Mundaca L. etc.

\section{Research Methods}

One of the most important factors, that determine the current situation in the power industry and create limitations for further development, is its "politicization". When territorial expansion led to the growth of the energy system to the scales of the state, it became an instrument of politics in various forms: social, economic, development of regions, security, integrity and so on, - in fact, that's the way it is nowadays. However, if its "political" component constituted earlier a tool for developing the industry, now it is increasingly becoming a limiting factor. Primarily this is manifested in the practice of cross-subsidization, i.e. in the support of some sectors, regions or customers at the expense of others. "Politicization" is an institutional problem, since it is caused by non-economic factors, by the need to protect the interests of a particular group of people.

The second important factor having a significant impact on the state of modern electric-power industry is the development of institutional competition, in particular, regarding the efficient use of the property institution. One of the major objectives of the reforms was to create in the industry a competitive market which could ensure the most efficient operation of electric power and its constituent entities. It should be noted that the possibility of creating a perfectly competitive market in the industry is considerably limited by the technological and technical conditions.

\section{Analysis Result}

Let us consider the main aspects which determine or influence the state of institutional relations in the current market model.

From a consumer perspective, the level of market imperfections of electricity (capacity) is rather high due to the following:

- institutional structure of electric power is far from effective functioning;

- institutional changes are inert and largely determined by the National Energy Strategy;

- unlike overseas electricity markets, our market does not ensure competition for the customer who has substantial limits in selecting (changing) the electricity supplier;

- access to the wholesale market with more attractive price conditions is connected for the customer with huge financial and time costs;

- consumers which are not participants of the wholesale market do not have the possibility to influence the competition of the energy suppliers nor the purchase of energy and services in the public trading floors, etc.;

- extremely low level of competition in retail markets where failed the expectations for effective competition between energy supply companies for their customers, for encouraging them to introduce mechanisms of reducing prices and improving the quality of service.

In addition, the analysis of the development of this sector in the Russian model demonstrates:

- the imperfection of the mechanisms of tariff regulation and, as a result, the uncontrolled growth of tariffs for transmission and distribution of electricity;

- the complexity of procedures and the high cost of connection to the supply;

- the system of cross-subsidization remains, which considerably distorts market signals and incentives both in the current state and while formulating the industry development strategy.

\section{Discussion}

All of these produce a system of negative signals to the customers, and their possible reaction options can result in reducing consumption, increasing energy efficiency or developing their own generation. For the last two or three years industrial and other consumers have been leaving the market and have focused on the development of local energy supply systems. This is mainly due to the inefficiency of institutional changes in the electric-power industry.

The result is a kind of an institutional trap: the more active consumers are to leave the centralized electric-power supply, the higher the price burden is on the remaining customers and the stronger the negative signals are, forcing to reduce consumption or to create one's own power supply system.

Due to the lack of the institutional environment and to the impossibility for consumers to abandon the expensive energy (demand price-elasticity of the market equals zero), providers overcharge prices (according to the experts, by 20 - 
40\%).

Another factor, which started considerably transforming the electric-power industry last decade, is the development of new technologies. In connection with breakthroughs in the development of intellectual technologies significant changes took place in the trends of development of the electric-power industry, which primarily affected the transition to a new technological order. The traditional way of developing the electric-power industry involved primarily increasing new capacities and facilities as well as upgrading particular types of the equipment with better characteristics of existing engineering capability, which could allow the industry to meet the growing demand of the society and the economy for a hundred years. The major industrialized nations have analyzed possible ways of solving the above-mentioned problems, and the results of this analysis showed that there are serious constraints for energy developing in the framework of traditional approaches (Kobets, Volkova, 2010). However, the development of new technologies requires a change of institutional relations. The state of formal and informal institutions should be taken to a new level.

Understanding the need for fundamental changes of the industry functioning model brought foreign countries to search new approaches to the solution: the new approach was based on the classical theory of strategic management which is a system of views on the image of the object of study in future, i.e. it suggests strategic vision.

Thus, the starting point for the development of the concept of the intellectual energy engineering was a clear vision of the energy system meeting the requirements of the future society and of all the interested parties: government, science, economy, business, consumers and other institutions.

The strategic vision of institutional changes in energy engineering can be represented as a set of the following points:

1. All the institutions: government, business, science, households, etc., are interested in the development of energy engineering, as it is the infrastructural basis for developing a country's economy. Goods and services produced in the industry are of high social significance and have virtually no substitutes.

2. Optimization of the quality and efficiency of the use of all kinds of resources (fuel, technical, managerial, informational, etc.) and energy assets.

3. In today's and future society energy is considered to be a source (an instrument or means) providing individuals and society with some consumer values: vital goods, a level of comfort and so on.

4. Meeting the need of the XXI-st century society for electric energy together with considerable reducing the pressure on the planet's ecology.

5. Changes in the behavior of electricity consumers, including households. The law of rising necessities should be taken into consideration. In service market the increasingly important role is played by "new" institutional units of the services market, the occurrence of which is predetermined by the relevancy to satisfy human needs (Burganov, 2013).

The resulting diversity and differentiation of requirements or values radically change traditional views on the role, place and purpose of energy development: the concept of intellectual energy engineering comes from the need to meet the requirements of all interested parties at any time and in any place.

Thus, within the concept of energy engineering development the task set is not to provide a certain volume of energy with prescribed (by someone) parameters and characteristics, but to provide a consumer with the opportunity to choose on his own how much, where, how and the energy of what characteristics to consume and (or) to produce giving him the possibility to get both today and in the future the necessary benefits, the level of comfort as well as the creation of an effective institutional environment.

The concept of intellectual energy engineering is based on a quite deep analysis of trends in the development of society, assessing current and forecasted challenges and threats, emerging and anticipated requests, motivation and behavior of both consumers and other interested parties, determined by directions of general technical and technological development influencing the requirements to the energy sector (Elektroenergetika Rossii 2030:. 2008). Within 15-20 years its implementation will lead to the crucial changes of the energy sector and its efficient and reliable operation for the benefit of society. One of the key solutions for meeting the objectives of the concept is the trend of a gradual shift toward distributed generation based on intelligent technologies that make it possible to arrange for functioning and controlling such systems in real time.

\section{Conclusion}

Introduction and active development of increasingly important sector of distributed energy engineering require a change in the paradigm of development of electric-power industry and an adjustment of legal framework, namely it is necessary to: 
- ensure, as a matter of priority, the observability of this sector, which requires to design and launch collecting relevant reporting information;

- change the institutional rules of pricing for network-energy services, comprising: a) the transition from the boiler tariff scheme for network-energy services where the "boiler" is formed at the level of the subject of the Russian Federation, to the municipal boiler tariffs for network-energy services for networks of $35 \mathrm{~kW}$ and below; b) for low-power generating units operating for specific customers, the departure from the compulsory application of boiler tariffs for electricity sold by them and start payment only for the necessary level of reserving network capacities;

- introduce and regulate the development of municipal schemes of energy engineering for regularizing the processes of managing the development of energy distributing infrastructure and low-capacity cogeneration units;

- organize cooperation of the institutions of the national economy to coordinate the development of municipal electric engineering and large electric-power industry at the federal level and the level of the Russian Federation.

Today the solution of these problems should result for Russia in creation of effective institutional environment of electric-power industry against the background of slowing down the pace of economic growth following the sanctions from a number of countries.

\section{Acknowledgement}

The study was performed under the project 14-02-00041 Russian Foundation for Humanities.

\section{References}

Burganov, R.A. (2013). Processy sozdaniya institutsionalnogo polya rynka uslug. Aktualnye problemy ekonomiki I prava, 2(26), 20-29. Burganov, Rais Abrarovich (2014). "Institutional Aspects of Development of Power Industry." American Journal of Educational Research, vol. 2, no. 7 (2014): 552-554. doi: 10.12691/education-2-7-19. 553.

Elektroenergetika Rossii 2030: (2008). Tselevoye videniye / pod red. B.F. Vayzihera. M.: Alpina Biznes Buks, 2008. 360 p. Kobets, B.B., Volkova I.O. (2010). Innovatsionnoye razvitiye elektroenergetiki na baze kontseptsii. Moskou.

North, D. (1990). Institutions, Institutional Change and Economic Performance. N.Y. Cambridge University Press. 1990. 79. 